\title{
Gilt rearing impacts on sow performance and longevity - a review
}

Jaroslava Belkova, PhD; Miroslav Rozkot, PhD

\section{Summary}

Lifetime performance and longevity are very important parameters of profitability in sow breeding. Opportunity to improve lifetime performance and longevity may be found in the rearing period and preparation of gilts for their future reproductive role. With the aim to prevent premature culling, it is possible to influence body condition, limb condition, mammary gland development, and proper function of the reproductive tract through nutrition, technology, and rearing strategies. Nutrition plays a very important role, as it can affect all the basic requirements for achieving satisfactory gilt performance. Selecting the most effective rearing strategy can be difficult because there are many factors affecting performance and longevity. The aim of this literature review is to provide upto-date information on how sow longevity and performance can be influenced through choice of gilt rearing strategies and the important area of nutrition.

Keywords: swine, gilt, nutrition, performance, longevity

Received: March 5, 2021

Accepted: May 26, 2021

\section{Resumen - Impacto de la cría de prim- erizas en la producción y la longevidad de la cerda - una revisión}

La producción de por vida y la longevidad son parámetros muy importantes de rentabilidad en la cría de las reproductoras. La oportunidad de mejorar el rendimiento y la longevidad de por vida se puede encontrar en el período de cría y en la preparación de las primerizas para su futura función reproductora. Con el objetivo de prevenir el desecho prematuro, es posible influir en la condición corporal, la condición de las patas, el desarrollo de la glándula mamaria, y el funcionamiento adecuado del tracto reproductivo a través de estrategias de nutrición, tecnología, y crianza. La nutrición juega un papel muy importante, ya que puede afectar a todos los requisitos básicos para lograr un desempeño satisfactorio de las primerizas. La selección de la estrategia de cría más eficaz puede resultar difícil porque hay muchos factores que afectan la producción y la longevidad. El objetivo de esta revisión bibliográfica es proporcionar información actualizada sobre cómo se puede influir en la longevidad y la producción de las cerdas mediante la elección de estrategias de cría de las primerizas, y la importante área de la nutrición.

\begin{abstract}
Résumé - Impact de l'élevage des cochettes sur les performances et la longévité des truies - une revue
\end{abstract}

Les performances à vie et la longévité sont des paramètres très importants de la rentabilité de l'élevage des truies. La période d'élevage et la préparation des cochettes pour leur futur rôle reproducteur peuvent permettre d'améliorer les performances à vie et la longévité. Dans le but de prévenir l'abattage prématuré, il est possible d'influencer l'état corporel, l'état des membres, le développement de la glande mammaire, et le bon fonctionnement de l'appareil reproducteur grâce à la nutrition, la technologie, et les stratégies d'élevage. La nutrition joue un rôle très important car elle peut affecter toutes les exigences de base pour obtenir des performances satisfaisantes des cochettes. La sélection de la stratégie d'élevage la plus efficace peut être difficile car de nombreux facteurs affectent les performances et la longévité. L'objectif de cette recension de la littérature est de fournir des informations à jour sur la façon dont la longévité et la performance des truies peuvent être influencées par le choix des stratégies d'élevage des cochettes et le domaine important de la nutrition.
$\mathrm{I}$ $\mathrm{n}$ addition to litter size and weight, longevity is a crucial indicator of sow herd profitability. Therefore, it is important to create optimal conditions for sows in the individual phases of their reproductive cycles. Even as producers can choose gilts in optimal physical condition, with a sufficient number of teats, and place them into a near-optimal environment, this still is no guarantee of achieving breeding success and longevity. It is important to begin giving special attention to gilts much earlier as they are being reared before inclusion into the breeding herd to ensure appropriate body development and onset of reproductive functions.

Longevity is associated with the level of culled sows. Although yearly replacement of $40 \%$ of sows is considered economically advisable, it varies within a wide range (62\% for some US farms in 2019) ${ }^{1}$ and depends upon the conditions and management of each herd. Even higher yearly replacement levels can be economically acceptable if breeding herd females are sufficiently productive, however, animal welfare and long-term economic viability may be concerns when replacement levels are above $50 \%$.

Department of Pig Breeding, Institute of Animal Science Prague, Kostelec nad Orlici, Czech Republic.

Corresponding author: Dr Jaroslava Belkova, Komenskeho 1239, Kostelec nad Orlici, 517 41, Czech Republic; Tel: +420 494 323291 ; Email: belkova.jaroslava@vuzv.cz.

This article is available online at http://www.aasv.org/shap.html.

Belkova J, Rozkot M. Gilt rearing impacts on sow performance and longevity - a review. J Swine Health Prod. 2022;30(1):10-16. 
In a 2018 summary for the United States, PigCHAMP reported a mean culling rate of $45.06 \% .^{2}$ The total culling rate included voluntary and involuntary culling. For voluntary culling, Mote et $\mathrm{al}^{3}$ recommended obtaining at least three litters from each sow to return the investment in the sow. Selecting sows that can remain in the breeding herd for a longer time is beneficial for reproductive performance. The authors assume that the main reasons for culling do not change substantially over time, and this has been documented by publications over the years. Friendship et $\mathrm{al}^{4}$ cited reproductive disorders (43\%), limb problems (12\%), and low performance (7\%) among the most frequent causes for culling. Stupka et $\mathrm{al}^{5}$ reported the most frequent causes for culling from farms to be reproductive issues (44\%), musculoskeletal issues (19\%), and other reasons such as milk production, health condition, and age (28\%). Hadaš et $\mathrm{al}^{6}$ performed an evaluation according to parity order and found the highest levels of culling were reached after the first and second parities, with $22 \%$ or $21 \%$ of sows culled from the sow herd, respectively, with reproductive failures (34\%), musculoskeletal disorders (27\%), and poor performance (18\%) being the most frequent causes of culling. Poor mammary gland condition and health condition each represented less than $10 \%$ of the cases. ${ }^{6}$ The percentage of sows culled and reason for culling are listed in Table 1. These reasons for culling indicate the areas that present room for improvement during the rearing and preparation of gilts. However, high level of involuntary culling can also be an indicator of poor staff skill or poor sow welfare.

\section{Birth weight}

Selection for improved prolificacy has resulted in larger litter sizes and thereby increased the proportion of low birth weight (LBW) piglets. ${ }^{10}$ It is documented that LBW piglets have poorer grow-finish performance and carcass quality. ${ }^{11-14}$ Birth weight also has a relationship with subsequent reproductive performance in gilts. Almeida et $\mathrm{al}^{10}$ investigated the effects of birth weight on reproductive tract and ovarian follicle development in 150-day-old gilts. Twenty-eight female pigs of different birth weight ranges (high birth weight [HBW]: 1.8-2.2 kg; LBW: 0.8-1.2 kg) from higher-parity commercial sows were reared until 150 days of age. Their body weights (BW) were recorded at weaning, end of nursery, and end of grower-finisher phases. The gilts with LBW showed significantly lower BW and slower average daily gain during all phases of production compared to those in the HBW group $(P<.01)$. Most biometrical measurements of the reproductive tract were similar between the experimental groups except vaginal length and the gonadosomatic index (relative ovarian weight) were affected by birth weight class $(P<.05)$. The LBW females also showed fewer medium size (3-5 mm; $P<.01)$ ovarian follicles, tended to have fewer pre-antral follicles $(P<.07)$, and more atretic follicles per ovarian cortex area $(P<.05)$. Therefore, in addition to affecting postnatal growth performance, birth weight influenced vaginal length and the follicular dynamics, which may impair the reproductive performance of replacement gilts.

Similarly, Vallet et $\mathrm{l}^{15}$ found that total uterine length was positively associated with birth weights. Their results indicate that colostrum consumption, birth weights, preweaning growth rate, number weaned, and parity were associated with gilt development traits during later life.

Knauer ${ }^{16}$ found that greater piglet birth weight was related to the proportion of gilts farrowing a litter. Greater piglet preweaning growth was related to the proportion of gilts that farrowed a litter and lifetime reproductive throughput. Hence, management strategies that improve colostrum production, milk production, and preweaning piglet growth should enhance subsequent lifetime productivity. Increased weaning age by 1 day added to a gilt's subsequent reproduction by 0.185 piglets/year, and gilts that were crossfostered were $2.45 \%$ less likely to farrow a litter. ${ }^{15}$

\section{Mineral nutrition}

It is well understood that nutrition plays an integral role in the development of a gilt. Gilts are to be bred rather than fattened so diets designed for finisher pigs may not meet the physiological needs of the replacement gilt. ${ }^{17}$ Replacement gilts in the grower-finisher phase should receive specifically designed diets. Modern maternal line genotypes are more sensitive to nutritional management because their appetites are lower and they have exceptional lean growth potential. ${ }^{18}$ Today's gilts are therefore more susceptible to deficiencies in nutrition, environment, and management.

To achieve better rearing performance in sows and improved growth of their pigs requires an adequate mineral supply, including trace elements. Foundation and skeletal development, birth weights, milk yield, and growth can be negatively influenced when minerals do not meet the animal's needs. Sow requirements for calcium $(\mathrm{Ca})$, phosphorus (P), sodium, and chlorine, as well as zinc, iodine, and selenium are not met by feeding natural plant feeds, and so it is necessary that these be supplemented. ${ }^{19}$

One of the primary goals of replacement gilt nutrition is to increase mineral stores by maximizing bone mineralization. Finisher pig diets may not supply

Table 1: The percentage of sows culled and reason for culling

\begin{tabular}{|c|c|c|c|c|}
\hline & Hadaš et $a^{6}$ & Engblom et $\mathrm{al}^{7}$ & Balogh et $\mathrm{al}^{8}$ & Wang et al9 \\
\hline Reproductive failure & 34.0 & 26.9 & 47.0 & 34.65 \\
\hline Feet and leg problems & 27.0 & 8.6 & 25.0 & 10.53 \\
\hline Poor performance & 18.0 & 9.5 & NA & 5.0 \\
\hline Udder problems & 8.0 & 18.1 & NA & 6.71 \\
\hline Old age & 1.0 & 18.7 & 7.0 & 1.56 \\
\hline Other & 10.0 & NA & 5.0 & 2.26 \\
\hline
\end{tabular}

$\mathrm{NA}=$ not available 
the correct balance of minerals to satisfy the nutritional requirements for reproductive performance and for cartilage and bone formation and integrity. ${ }^{20,21} \mathrm{It}$ is generally recommended that $\mathrm{Ca}$ and $\mathrm{P}$ be provided at levels greater than typically found in the grower-finisher diets in order to prevent females from experiencing locomotion problems later on due to excessive depletion of mineral stores during lactation periods. ${ }^{22}$ Johnston $^{23}$ states that increasing bone mineralization has been shown to boost longevity of sows.

In gilt development diets, a minimum digestible $\mathrm{Ca}: \mathrm{P}$ ratio of $1: 1$ is needed, and it varies depending on the P level. For example, it may be $1.25: 1$ if $\mathrm{P}$ meets the recommendations for 50 to $80 \mathrm{~kg}$ of live weight. ${ }^{24}$ Also, Ca recommendations to maximize bone mineralization are greater than for growth (less than 1.35:1 if the concentration of $\mathrm{P}$ is at the requirement) ${ }^{25}$ Even though growing gilts are generally provided ad libitum access to feed, the rapid growth rates in current genetic lines and high incidence of leg problems can lead to lameness. Lameness disorders account for $22.5 \%$ of sow cullings, ${ }^{26}$ and lameness is one of the most important causes of reduced longevity and poor welfare in replacement gilts. The problem is exacerbated by inappropriate housing and diet during the rearing period. ${ }^{27}$ Attempts to improve skeletal integrity by reducing growth rate through energy restriction have not been successful. ${ }^{28}$ The application of management tools that are consistent with physiological processes is therefore required to reduce lameness issues.

A P deficiency can cause growth rate and bone mineralization to be suboptimal, albeit without effects on osteochondrosis (OCD).$^{29}$ Osteochondrosis is a frequent cause of lameness and consequently a reason for culling young sows. Genetic selection could be used to reduce the prevalence of OCD, although this may be difficult initially because the growth potential of lean tissue is genetically associated with OCD. ${ }^{29}$ Other factors that could influence OCD progression are not well known. Heritability estimates of OCD score were similar for both Landrace and Yorkshire breeds, averaging about 0.21, in a genetic study by Yazdi et al. ${ }^{30}$ The correlations between breeding values for longevity and OCD were low (on average 0.07 , adjusted for genetic trends) but nevertheless significant $(P<.01)$ and in a favorable direction, as greater OCD was associated with greater risk of being culled.

Fabà et $\mathrm{al}^{31}$ supplemented the basic diet of growing gilts with organic microminerals (copper, manganese, and zinc at 10,20 , and $50 \mathrm{mg} / \mathrm{kg}$, respectively) and observed this to enhance bone strength and bone density. Another diet with additional methionine (at a 102\% methionine:lysine ratio) increased the proportion of highly dense bone (as measured by Hounsfield values). The combination of these two dietary treatments reduced OCD lesion scores compared to the basal diet.

Quinn et $\mathrm{al}^{17}$ reported improved locomotion scores, higher bone mineral density, and lower cartilage lesion scores in gilts fed a restricted diet formulated for fat rather than lean deposition (with higher energy content and lower lysine content than a finisher diet) and with increased levels of copper, zinc, and manganese. Hartnett et $\mathrm{al}^{27}$ used manganese, zinc, and copper at 206\%, 122\%, and 179\%, respectively, of National Research Council recommendations for gestating and lactating sows. The benefits of supplementing these minerals could lead to potential improvements in the lifetime performance of replacement gilts and the longevity of sows. There is clear indication that replacement gilts can benefit in terms of limb health and their overall welfare from being reared in female-only pens (as gilts reared with intact male finisher pigs are exposed to high levels of sexual mounting and aggression, which may cause physical damage) and a mineral-supplemented diet. ${ }^{29}$

Although nutritional deficiencies reduce bone quality and can influence OCD, inconsistent research findings in this area raise questions as to the potential of nutritional supplements. These dietary measures can potentially act to prevent OCD or reverse early stages of OCD, but they cannot be used to heal advanced stages of OCD. More research is needed to understand OCD pathogenesis and progression, and the interactions with growth rate, genetics, and management.

\section{Mammary gland development}

Another important factor for strong breeding performance and longevity is sufficient milk production. Improvements in sow milk yields through the years mostly have been achieved via nutrition and management because a recent study demonstrated that 21 years of genetic selection (from 1977 to 1998) increased piglet birth weight but had no effect on sow milk yield. ${ }^{32}$ Therefore, it is necessary to devise management strategies that optimize milk yields, and one possible way is to influence mammary gland development. The number of mammary cells present at the onset of lactation has a major impact on potential sow milk yield. ${ }^{33}$ Several studies have shown that gilt nutrition in the periods of rapid mammary accretion occurring during prepuberty, gestation, and lactation can affect mammary development. ${ }^{34}$ Various nutritional treatments can bring about a $27 \%$ to $52 \%$ increase in mammary tissue weight. A study where a 20\% feed restriction was imposed in the prepubertal period showed that mammary parenchymal mass decreased by $26.3 \% .{ }^{35}$ Ad libitum feeding during the prepubertal period increased mammary parenchymal weight by $36 \%$ to $52 \%$. It was clearly established that feed restriction from 90 days of age (but not before 90 days) until puberty had detrimental effects on mammary development in pigs. ${ }^{36}$

According to Farmer et al, ${ }^{37}$ gilts that were obese (36 mm backfat) or too lean (12-15 $\mathrm{mm}$ backfat) in late gestation had less-developed mammary tissue. Gilts of similar BW at mating were fed different amounts of feed throughout gestation (1.30, 1.58 , or 1.82 times maintenance requirements) to achieve three levels of backfat thickness (BF) on day 109 of gestation, namely, 12 to $15 \mathrm{~mm}$ (lean), 17 to $19 \mathrm{~mm}$ (medium), and 21 to $26 \mathrm{~mm}$ (fat). Parenchymal tissue mass was significantly reduced in lean gilts, with 1059, 1370 , and $1444 \mathrm{~g}$, respectively, for lean, medium, and fat gilts. These findings demonstrate that, within this range of body conditions, being too thin at the end of gestation is detrimental for mammary development, whereas medium or fat body conditions had no negative impact. Underfeeding should be avoided to ensure maximal amount of parenchymal tissue mass. Overfeeding energy in late gestation also seems to be detrimental. An experiment was carried out to study the effect of protein intake during the growing-finishing period on mammary development in gilts. ${ }^{35}$ Reducing dietary crude protein from $18.7 \%$ to $14.4 \%$ from 90 days of age until puberty did not affect mammogenesis. Neither the amount of parenchymal tissue nor the composition of mammary parenchyma was altered. This suggests that total feed intake is more important than protein intake to ensure proper mammary development of growing gilts.

Even though research has been conducted to evaluate the nutritional control of mammogenesis in pigs, it is evident that much 
remains to be learned before the best nutritional strategy to enhance mammary development can be formulated. Feeding certain plant extracts with estrogenic or hyperprolactinaemic properties may also prove beneficial in stimulating mammary development within specific physiological periods. ${ }^{34}$ An attempt was made to stimulate mammary development in gilts by providing a dietary source of estrogen. When $2.3 \mathrm{~g} /$ day of the phytoestrogen genistein was added to a standard soybean meal-based diet of growing gilts from 90 to 183 days of age, there was a $44 \%$ increase in mammary parenchymal cells at the end of the treatment period. ${ }^{38}$ Genistein is an isoflavone found in legumes, especially soybeans. ${ }^{39}$ In another study, Farmer et $\mathrm{al}^{40}$ used the plant extract silymarin (from Silybum marianum, generally known as milk thistle). Four grams of silymarin was fed twice daily to gilts from 90 to 110 days of gestation, at which time animals were slaughtered to collect their mammary glands. Even though feeding silymarin led to a $51.8 \%$ increase in circulating prolactin concentrations 4 days after the onset of treatment, this increase was transient and was not large enough to elicit beneficial effects on mammary development. ${ }^{40}$

Feed mycotoxins can impact mammary gland and reproductive tract development most likely through their estrogenlike activities. Stephan et $\mathrm{al}^{41}$ found mycotoxins were passed via milk from sows to piglets on the basis of zearalenone/azearalenol-concentration in piglet bile and a tendency towards lower uterus weight among piglets having zearalenone-influence during gestation and lactation.

The number of teats is an important criterion for replacement gilts. According to Drickamer et $a 1,{ }^{42}$ the number of pig teats is significantly influenced by genetics, principally from the dam's side. The proportion of males in a litter appears to be related to the anogenital distance of the gilt littermates, possibly as a result of an intrauterine position effect. A greater number of teats on the dam and a lower proportion of males in the litter were associated with a greater number of teats on the gilt.

\section{Nutrient concentrations and feeding strategy}

Compared to typical finishing pig diets, replacement gilt diets should contain higher concentrations of vitamins A and E, calcium, phosphorus, selenium, chromium, and zinc because highly prolific gilts reach puberty with limited reserves of protein and body fat and they continue to grow during their first gestation. ${ }^{18} \mathrm{~A}$ vitamin premix should contain elevated levels of fat-soluble vitamins A, D, E, and K, as well as water-soluble vitamins choline, biotin, and folic acid, whose levels are relatively low or absent in typical finishing diets.

Energy and amino acid density of diets for each phase of growth will depend on lean growth potential of the gilt and voluntary feed intake. Replacement gilts are typically provided ad libitum access to a diet lower in energy, protein, or both than those diets fed to slaughter pigs to avoid excessive body fat. ${ }^{43}$ This also allows for slightly slower growth, which limits mature body size thereby preventing feet and leg problems and excessive fat gain. Long et $\mathrm{al}^{44}$ reported that sows fed a high energy, high protein diet ad libitum from 120 to 180 days of age had significantly poorer longevity through four parities than did gilts fed a high energy, low protein diet ad libitum or a restricted-fed high protein diet (35\% vs 56\% and 55\%, respectively). Similarly, Hoge and Bates ${ }^{45}$ found that slower growing gilts had a lower risk of being culled in their study.

Feeding modern high-lean gilts ad libitum is most practical for most production systems, particularly when gilts are housed in groups. Limit feeding may be more appropriate for low- and mediumlean maternal gilts. Limit feeding involves providing replacement gilts ad libitum access to a diet until a month or two before breeding. The ad libitum diets are similar to grow-finish diets, allowing maximum expression of the animal's genetic potential for growth rate and backfat. Feed intake is then restricted to approximately $85 \%$ to $90 \%$ of ad libitum until 10 to 14 days before mating. When restricting the diet, energy should be restricted but not amino acids, vitamins, or minerals. Therefore, concentrations of these nutrients need to be adjusted upwards in the diets accordingly. ${ }^{43}$ Facility design may make it difficult for producers to feed a restricted diet to replacement females. When gilts are housed and fed in groups, it is difficult to ensure the correct amount of feed is ingested on an individual basis because all gilts do not consume feed at the same rate. Unless producers have individual stalls or an electronic feeding system available for potential breeding herd replacement females, it will be difficult to implement a restricted feeding program. ${ }^{46}$ Feeding a high-fiber diet that is lower in energy concentration is an alternative that allows for a daily feed intake closer to ad libitum levels. The effects of increased consumption time, gut fill, and satiety may partially alleviate competition and variability in individual feed intake in group feeding situations, but it also may present challenges related to feed delivery systems and manure handling. The dietary fiber content is significant because of satiety, proper digestion, and effect on intestinal microflora, and it affects sow longevity too. Koketsu et $\mathrm{al}^{47}$ found evidence that adding fiber to gestation diets may improve sow longevity.

\section{BF and body condition}

Backfat thickness is important in gilts and primiparous sows, as it is related to sow longevity. Some authors suggest that the ideal $\mathrm{BF}$ range of gilts would be between 16 and $20 \mathrm{~mm}$, although this range may vary and is clearly influenced by sow genetics. Flisar et $\mathrm{al}^{48}$ found that gilts with thicker backfat had smaller litters in the first three parities. Sows with $10 \mathrm{~mm}$ thicker backfat farrowed more litters ( 0.41 on average) per lifetime and were culled 50 days later.

Farmer et $\mathrm{al}^{49}$ found it beneficial for primiparous sows to have greater BF (ie, 20 to $26 \mathrm{~mm}$ ) at the end of gestation to achieve optimal mammary development and greater litter body weight gain in the subsequent lactation. The results indicate that greater $\mathrm{BF}$ in late gestation of primiparous sows tends to increase litter weight gain due to higher milk production possibly related to better development and preparation of the mammary glands. Given the improvement in piglet weight gain was modest (8.5\%), fatter sows lost more BF for the same piglet live weight, and that the strongest correlation between $\mathrm{BF}$ and those parameters measured in the udder occurred with nonparenchymal tissue, it is recommended to keep primiparous sows at the end of gestation in a $\mathrm{BF}$ range between 15 and $26 \mathrm{~mm} .{ }^{50}$

The primary goal in the final part of rearing is to encourage early expression of pubertal estrus and successfully mate gilts while they continue to grow towards their mature body size. Various strategies are possible. The specific approach may vary from farm to farm depending upon genetics and management practices. Although severe protein restrictions or imbalanced intake of essential amino acids have been demonstrated to delay the onset of puberty, moderate protein 
restriction during the rearing period does not appear to influence age at first estrus in gilts. Older literature indicates that selected replacement gilts should be limit fed energy from 100 to $104 \mathrm{~kg}$ of BW or until 2 weeks prior to mating so they will not become too fat. Nevertheless, Foxcroft et al, ${ }^{51}$ Williams et al, ${ }^{52}$ and Gill ${ }^{53}$ presented evidence that fatness is not an issue with modern lean maternal line genotype females, which deposit and mobilize lean tissue with little impact on fat tissue deposits. Development of ultra-lean genotypes has had negative effects on longevity and lifetime productivity of replacement gilts. This has led to a need for enhancing and conserving fatness in gilts by feeding a low protein $\operatorname{diet}(11.3 \%$ crude protein, $0.45 \%$ lysine, 13.0 MJ digestible energy $/ \mathrm{kg}$ ) before and during pregnancy to restrict lean gain and increase fat deposition..$^{53}$ In medium- or low-lean genotypes, gilts will tend to consume more energy than is needed to achieve ideal body condition, thus becoming too fat. Therefore, limit feeding is advised with those genotypes after selection has occurred.

\section{Gill ${ }^{54}$ found that increases in fatness} achieved by diet during rearing are transient. Any residual effects had disappeared by the time the first litter was weaned. The potential protective benefits to sow longevity from feeding a low protein diet during gilt rearing probably result from long-term reduction in sow BW and, in turn, reduced risk of foot and leg injury. A more holistic approach would be to consider how to improve the overall welfare and fitness of gilts and sows.

\section{Management}

Management of the gilt up to when the first litter is weaned has a major influence on lifetime productivity and, consequently, weaning capacity. Size of the first litter has a strong correlation with subsequent litter sizes, ${ }^{55}$ so achieving a large first litter can be a good indicator of more piglets born and weaned in a sow's lifetime. Correct management during gilt rearing will positively influence longevity, thereby increasing litters per sow lifetime, which is a key factor in maximizing weaning capacity. The current criteria for selecting replacement gilts for breeding are excellently described in the review by Malopolska et al. ${ }^{56}$

\section{Conclusion}

Nutrition during gilt rearing plays an important role as it can affect growth rate, optimal body condition, early heat onset, reproductive tract and mammary gland development, and good limb condition. It is important to focus on welfare and fitness and to create good environmental conditions from the time of a gilt's birth and continue all through rearing. As reproductive failures are the most common cause of culling, it would be appropriate to further investigate the effect of nutrition and feeding strategy on the development and functionality of the reproductive tract during rearing and its relationship to the lifetime performance of the sow. Due to the increased number of piglets born per litter, it is also appropriate to focus on a nutritional strategy that enhances mammary development to achieve increased milk production during lactation.

\section{Acknowledgments}

This work was supported by the Ministry of Agriculture of the Czech Republic institutional support MZE-RO 0718.

\section{Conflict of interest}

None reported.

\section{Disclaimer}

Scientific manuscripts published in the Journal of Swine Health and Production are peer reviewed. However, information on medications, feed, and management techniques may be specific to the research or commercial situation presented in the manuscript. It is the responsibility of the reader to use information responsibly and in accordance with the rules and regulations governing research or the practice of veterinary medicine in their country or region.

\section{References}

* 1 . Piñeiro C. Big pig data is changing the industry. Benchmark. Spring 2020:69. Accessed March 2021. https://www. pigchamp.com/flipbooks/benchmarkmagazine/2020/USA/index.html\#6/z

*2. PigCHAMP. USA 2018 Year Summary. Benchmark. Spring 2019. Accessed March 2, 2020. https://www.pigchamp.com/ news/benchmark-magazine/articles/ usa-2018-year-summary-2019
*3. Mote BE, Stalder KJ, Rothschild MF. Reproduction, culling, and mortality levels on current commercial sow farms. Animal Industry Report: AS 654, ASL R2360. 2008. Accessed March 2, 2020. https:// lib.dr.iastate.edu/cgi/viewcontent. cgi ?article $=1399 \&$ context=ans_air

4. Friendship RM, Wilson MR, Almond GW, McMillan I, Hacker RR, Pieper R, Swaminathan SS. Sow wastage: reasons for and effect on productivity. Can J Vet Res. 1986;50:205-208.

5. Stupka R, Šprysl M, Čítek J, Okrouhlá M. Embryonální mortalita a plodnost prasat [Embryonic mortality and fertility of pigs]. Aktuální problémy chovu prasat. 2005;179-187.

6. Hadaš Z, Schild M, Nevrkla P. Analysis of reasons for culling of sows in production herd. Research in Pig Breeding. 2015;9(2):1-5.

7. Engblom L, Lundeheim N, Dalin A-M, Andersson K. Sow removal in Swedish commercial herds. Livest Sci. 2007;106(1): 76-86. doi:10.1016/j.livsci.2006.07.002

8. Balogh P, Kapelański W, Jankowiak H, Nagy L, Kovacs S, Huzsvai L, Popp J, Posta J, Soltesz A. The productive lifetime of sows on two farms from the aspect of reasons for culling. Ann Anim Sci. 2015;15(3):747-758. doi: 10.1515/ aoas-2015-0020

9. Wang C, Wu Y, Shu D, Wei H, Zhou Y, Peng J. An analysis of culling patterns during the breeding cycle and lifetime production from the aspect of culling reasons for gilts and sows in Southwest China. Animals. 2019;9(4):160. doi:10.3390/ani9040160

10. Almeida FRCL, Alvarenga Dias ALN, Moreira LP, Fiúza ATL, ChiariniGarcia H. Ovarian follicle development and genital tract characteristics in different birthweight gilts at 150 days of age. Reprod Domest Anim. 2017;52(5):756-762. doi:10.1111/rda.12976

11. Hoy S, Lutter C, Puppe B, Wähner M. Correlations between the vitality of newborn piglets, teat order, mortality, and live weight development up to weaning. Article in German. Berl Munch Tierarztl Wochenschr. 1995;108:224-228.

12. Tuchscherer M, Puppe B, Tuchscherer A, Tiemann U. Early identification of neonates at risk: traits of newborn piglets with respect to survival. Theriogenology. 2000;54;371-388. doi: 10.1016/ S0093-691X(00)00355-1

13. Quiniou N, Dagorn J, Gaudré D. Variation of piglets' birth weight and consequences on subsequent performance. Livest Prod Sci. 2002;78:63-70. doi:10.1016/ S0301-6226(02)00181-1 
14. Bérard J, Kreuzer M, Bee G. Effect of litter size and birth weight on growth, carcass and pork quality, and their relationship to postmortem proteolysis. J Anim Sci. 2008;86(9):2357-2368. doi:10.2527/jas.2008-0893

15. Vallet JL, Calderón-Díaz JA, Stalder KJ, Phillips C, Cushman RA, Miles JR, Rempel LA, Rohrer GA, Lents CA, Freking BA, Nonneman DJ. Litter-of-origin trait effects on gilt development. J Anim Sci. 2016;94(1):96-105. doi:10.2527/jas.2015-9644

*16. Knauer M. Effects of preweaning factors on sow lifetime productivity. National Pork Board Research Report \#11146. Published February 2016. Accessed October 1, 2020. https://porkcheckoff. org/research/effects-of-preweaningfactors-on-sow-lifetime-productivity/

17. Quinn AJ, Green LE, Lawlor PG, Boyle LA. The effect of feeding a diet formulated for developing gilts between 70 $\mathrm{kg}$ and $\sim 140 \mathrm{~kg}$ on lameness indicators and carcass traits. Livest Sci. 2015;174:8795. doi:10.1016/J.LIVSCI.2014.12.016

18. Kraeling R, Webel S. Current strategies for reproductive management of gilts and sows in North America. J Anim Sci Biotechnol. 2015;6(1):3. doi:10.1186/2049-1891-6-3

*19. Arnhold W, Anke M, Hühn U, Richter G. Mengen- und Spurenelementbedarf und -versorgung von Sauen [Quantity and trace element requirements and supply of sows]. In: Proceedings of the 12. Mitteldeutscher Schweine-Workshop. Anhalt University of Applied Sciences; 2006:55-72.

20. Levis DG, Vernon DL, Rozeboom DW. Development of gilts and boars for efficient reproduction. In: Pork Industry Handbook. University of Nebraska, Digital Commons. 2005; Vol. 5:1-8.

21. Knauer MT, Cassady JP, Newcom DW, See MT. Gilt development traits associated with genetic line, diet and fertility. Livest Sci. 2012;148:159-167. doi:10.1016/j. livsci.2012.05.024

22. National Research Council. Nutrient Requirements of Swine. $10^{\text {th }}$ ed. National Academy Press; 1998.

*23. Johnston L. Gilt nutrition: nutritional programs enhance gilt development. National Hog Farmer. Published April 1, 1998. Accessed February 10, 2020. https://www.nationalhogfarmer.com/ mag/farming_gilt_nutrition_nutritional 24. National Research Council. Nutritional Requirement of Swine. $11^{\text {th }}$ ed. National Academy Press; 2012.
25. Lagos L, Walk C, Stein H. Requirement for digestible calcium at different dietary concentrations of digestible phosphorus indicated by growth performance and bone ash of 50 to $85 \mathrm{~kg}$ pigs. J Anim Sci. 2018;96(suppl 2):130-131. doi:10.1093/jas/sky073.241

26. Zhao Y, Liu X, Mo D, Chen Q, Chen Y. Analysis of reasons for sow culling and seasonal effects on reproductive disorders in Southern China. Anim Reprod Sci. 2015;159:191-197.

27. Hartnett P, Boyle L, Younge B, O'Driscoll K. The effect of group composition and mineral supplementation during rearing on measures of cartilage condition and bone mineral density in replacement gilts. Animals (Basel). 2019;9(9):637. doi:10.3390/ani9090637

*28. Crenshaw TD. Nutritional manipulation of bone mineralization in developing gilts. In: Proceedings of Allen D. Leman Swine Conf. University of Minnesota; 2003:183-189.

*29. Fabà L. Lameness and nutrition. Pig 333. Published February 25, 2019. Accessed March 2021. https://www.pig333.com/ articles/lameness-and-nutrition_14681 30. Yazdi MH, Lundeheim N, Rydhmer L, Ringmar-Cederberg E, Johansson K. Survival of Swedish Landrace and Yorkshire sows in relation to osteochondrosis: a genetic study. Anim Sci. 2016;71:1-9. doi:10.1017/S1357729800054849

31. Fabà L, Gasa J, Tokach MD, Font-iFurnols M, Vilarrasa E, Solà-Oriol D. Effects of additional organic micro-minerals and methionine on carcass composition, gait score, bone characteristics, and osteochondrosis in replacement gilts of different growth rate. Anim Feed Sci Technol. 2019;256:114262, doi:10.1016/j. anifeedsci.2019.114262

32. Silalahi P, Tribout T, Billon Y, Gogué J, Bidanel JP. Estimation of the effects of selection on French Large White sow and piglet performance during the suckling period. J Anim Sci. 2017;95:43334343. doi:10.2527/jas2017.148

33. Head RH, Williams IH. Mammogenesis is influenced by pregnancy nutrition. In: Batterham ES, ed. Manipulating pig production III. Australasian Pig Science Association; 1991:33.

34. Farmer C. Nutritional impact on mammary development in pigs: A review. J Anim Sci. 2018;96:3748-3756. doi:10.1093/jas/sky243

35. Farmer C, Petitclerc D, Sorensen MT, Vignola M, Dourmad JY. Impacts of dietary protein level and feed restriction during prepuberty on mammogenesis in gilts. J Anim Sci. 2004;82:2343-2351. doi:10.2527/2004.8282343x
36. Sorensen MT, Vestergaard M, Purup S, Sejrsen K. Mammary development, growth and plasma levels of IGF-I and IGF-binding proteins in gilts provided different energy levels from weaning to puberty. J Anim Sci. 2002;80(suppl 1):52.

37. Farmer C, Comi M, Duarte CRA, Vignola M, Charagu P, Palin M-F. Differences in body condition of gilts that are maintained from mating to the end of gestation affect mammary development. J Anim Sci. 2016;94:3206-3214. doi:10.2527/ jas.2016-0531

38. Farmer C, Palin M-F, Gilani GS, Weiler H, Vignola M, Choudhary RK, Capuco AV. Dietary genistein stimulates mammary hyperplasia in gilts. Animal. 2010;4:454-465. doi:10.1017/ S1751731109991200

39. Desmawati D, Sulastri D. Phytoestrogens and their health effect. Open Access Maced J Med Sci. 2019;7(3):495-499. doi:10.3889/oamjms.2019.086

40. Farmer C, Lapointe J, Palin M-F. Effects of the plant extract silymarin on prolactin concentrations, mammary gland development, and oxidative stress in gestating gilts. J Anim Sci. 2014;92:2922-2930. doi:10.2527/ jas.2013-7118

*41. Stephan K, Kauffold J, Bartol FF, Swalve HH, Wähner M. Effects of a perinatal zearalenone donation on mortality rate, weights during the suckling period and weights of reproductive organs from female piglets. In: Book of Abstracts of the $60^{\text {th }}$ Annual Meeting of the European Association for Animal Production 2009; Wageningen Academic Publishers; 2009:456. doi:10.3920/978-90-8686-670-0

42. Drickamer LC, Rosenthal TL, Arthur RD. Factors affecting the number of teats in pigs. $J$ Reprod Fertil. 1999;115(1):97-100. doi: 10.1530/ jrf.0.1150097

43. Whitney MH, Masker C. Replacement gilt and boar nutrient recommendations and feeding management. U.S. Pork Center of Excellence PIG 07-01-10. Published March 25, 2010. Accessed February 20, 2020. http://porkgateway. org/wp-content/uploads/2015/07/ replacement-gilt-and-boar-nutrientrecommendations1.pdf

44. Long TE, Stalder KJ, Goodwin RN, Halstead J, Anderson JM, Wyatt RL. Effect of gilt development diet on stayability to fourth parity in sows. J Anim Sci. 1998;76(suppl 2):52.

45. Hoge MD, Bates RO. Developmental factors that influence sow longevity. J Anim Sci. 2011;89(4):1238-1245. doi:10.2527/jas.2010-3175 
46. Stalder KJ, Long TE, Goodwin RN, Wyatt RL, Halstead JH. Effect of gilt development diet on the reproductive performance of primiparous sows. J Anim Sci. 2000;78:1125-1131. doi:10.2527/2000.7851125x

47. Koketsu Y, Dial GD, Pettigrew JE, King VL. The influence of nutrient intake on biological measures of breeding herd productivity. Swine Health and Prod. 1996;4:85-94.

*48. Flisar T, Malovrh Š, Urankar J, Kovač M. Effect of gilt growth rate and back fat thickness on reproductive performance. Acta Agric Slov. 2012;Supp13:199-203.

49. Farmer C, Martineau J-P, Méthot S, Bussières D. Comparative study on the relations between backfat thickness in late-pregnant gilts, mammary development and piglet growth. Transl Anim Sci. 2017;1(2):154-159. doi:10.2527/tas2017.0018
*50. Gasa J, Casanovas J. Gilt backfat thickness in late pregnancy, mammary development and piglet growth. Pig 333. Published August 22, 2019. Accessed February 20, 2020. https://www.pig333.com/ articles/do-gilts-with-greater-backfatthickness-produce-more-milk_15189/

*51. Foxcroft G, Beltranena E, Patterson J, Williams N, Pizzarro G. Physiological limits to maximizing sow productivity. In: Proceedings of the London Swine Conference 2005. London Swine Conference; 2005:29-46.

52. Williams N, Patterson J, Foxcroft GR. Non-negotiables of gilt development. $A d v$ Pork Prod. 2005;16:281-289.

*53. Gill P. Nutritional management of the gilt for lifetime productivity - feeding for fitness or fatness? In: Proceedings of the London Swine Conference 2007. London Swine Conference; 2007:83-99.
54. Gill BP. Body composition of breeding gilts in response to dietary protein and energy balance from thirty kilograms of body weight to completion of first parity. J Anim Sci. 2006;84:1926-1934.

55. Iida R, Piñeiro C, Koketsu Y. High lifetime and reproductive performance of sows on southern European Union commercial farms can be predicted by high numbers of pigs born alive in parity one. J Anim Sci. 2015;93(5):2501-2508. doi:10.2527/jas.2014-8781

56. Malopolska MM, Tuz R, Lambert BD, Nowicki J, Schwarz T. The replacement gilt: Current strategies for improvement of the breeding herd. J Swine Health Prod. 2018;26(4):208-214.

* Non-refereed references. 